\title{
RAPIDITY OF REMOVAL IN VITRO OF THE CUMULUS OOPHORUS AND THE ZONA PELLUCIDA IN DIFFERENT STRAINS OF MICE
}

\author{
HALINA KRZANOWSKA \\ Department of Animal Genetics, Jagiellonian University, \\ Krupnicza 50, Krakow, Poland
}

(Received 9th August 1971, accepted 1st September 1971)

Summary. The time needed for granulosa cell dispersal with hyaluronidase and for lysis of the zona pellucida with pronase and trypsin was estimated in vitro in fertilized and unfertilized eggs from four inbred strains, and one outbred strain of mice.

Granulosa cells were dispersed most rapidly in the C57 and most slowly in the CBA inbred strains. About $40 \%$ of the CBA ova remained undenuded after $2 \mathrm{hr}$ treatment. The time needed for removal of the zona pellucida with both enzymes depended on the strain of the female and on the physiological state of the eggs. It was shortest in unfertilized eggs ovulated on the day of treatment, and longest in fertilized and in old fragmented eggs.

The zona reaction (assessed by the difference between fertilized and unfertilized eggs in the time needed for lysis of the zona) was most effective in CBA strain eggs and least effective in KE inbred strain eggs. These differences may explain the varying incidences of supplementary spermatozoa found in the fertilized eggs of the tested strains.

\section{INTRODUGTION}

Inbred strains of mice differ with respect to fertilization rate and penetration of eggs by supplementary spermatozoa (Braden, 1958; Krzanowska, 1970). The results of the diallele crosses suggested that both the male and female strains are involved in these differences but nothing is known of the underlying mechanism.

Before entering the vitellus, the fertilizing spermatozoon has to pass through two barriers, the cumulus oophorus and the zona pellucida. This is accomplished by means of hyaluronidase, which disperses the granulosa cells, and proteolytic enzymes, which dissolve the zona pellucida. It is likely that spermatozoa from different strains are equipped with different quantities of these enzymes and/or the resistance of the cell layers surrounding the egg to the action of the enzymes is different. The present experiments were designed to test this second possibility.

Eggs from different mouse strains were tested in vitro for rapidity of removal of the cumulus oophorus by means of hyaluronidase and of the zona pellucida by 
means of two proteolytic enzymes, trypsin and pronase, which are known to be effective (Bowman \& McLaren, 1970).

The second object of this paper was to compare the resistance of the zona pellucida of fertilized and unfertilized eggs as a test of the effectiveness of the zona reaction in different strains of mice.

\section{MATERIAL AND METHODS}

The experiments were performed on mice belonging to an outbred strain and on mice of the following four inbred strains: C57BL (introduced from Edinburgh to Cracow in 1956 and bred in this Department since 1967), CBA/Kw, KP and $\mathrm{KE}$ (Krzanowska, 1965). The following abbreviations will be used throughout the paper: outbred, C57, CBA, KP and KE.

\section{Removal of cumulus oophorus}

Adult, 8- to 15-week-old females were given an intraperitoneal injection of 4 i.u. PMSG followed $48 \mathrm{hr}$ later by 4 i.u. HCG. Eighteen hours after the second injection, i.e. about $6 \mathrm{hr}$ after ovulation, the females were killed by cervical dislocation, their ova surrounded by granulosa cells were removed to a drop of $0.9 \% \mathrm{NaCl}$ and then transferred to $0.1 \mathrm{ml}$ hyaluronidase solution placed on a watch glass under paraffin oil. The preparations were kept at room temperature $\left(18\right.$ to $20^{\circ} \mathrm{C}$ ) for $2 \mathrm{hr}$ and inspected every $10 \mathrm{~min}$ under the dissecting microscope. The time needed for complete removal of the granulosa cells was noted. Two concentrations of testicular hyaluronidase (bovine) were tested, containing, respectively, $0.025 \%$ and $0.010 \%$ of enzyme dissolved in $0.9 \% \mathrm{NaCl}$.

\section{Removal of zona pellucida}

Eggs obtained following induced or spontaneous ovulation were tested. The eggs from induced ovulations were treated as described above. Females which ovulated spontaneously were divided into two groups: those with unfertilized ova and those paired with males. Only ova containing pronuclei, or at least a second polar body, were classified as fertilized. Both unfertilized and fertilized eggs were recovered at about 14.00 hours on the day of ovulation. In a few cases, the experiment was performed on the day following ovulation.

Denuded eggs, treated previously with a $0.025 \%$ solution of hyaluronidase, were transferred to $0.05 \mathrm{ml}$ of the proteolytic enzyme solution to be tested which had been placed in a watch glass under paraffin oil. The preparations, each containing the eggs of one female, were kept in a water bath at $38^{\circ} \mathrm{C}$ and inspected every $10 \mathrm{~min}$ under the low-power magnification. The time required for complete dissolution of the zona pellucida was noted.

Two enzyme solutions were tested, pronase and trypsin, in concentrations which permitted slow lysis of the zona lasting about $1 \mathrm{hr}$. From pilot experiments, the following pronase solution was found to be the most effective: pronase (Koch-Light Lab.) dissolved in a modified Krebs-Ringer phosphate fluid (771 mg NaCl, $37 \mathrm{mg} \mathrm{KCl}, 12 \mathrm{mg} \mathrm{MgSO} 4,142 \mathrm{mg} \mathrm{Na}{ }_{2} \mathrm{HPO}_{4}, 14 \mathrm{mg}$ $\mathrm{KH}_{2} \mathrm{PO}_{4}, 100 \mathrm{ml} \mathrm{H}$ O) to give a concentration of $0.00625 \%$ pronase. The acidity was adjusted to $\mathrm{pH} 6.7$ with a few drops of $1 \mathrm{~N}-\mathrm{HCl}$. 
Trypsin was used as a $0.25 \%$ solution dissolved in a $\mathrm{pH} 7.2$ phosphate buffer $\left(800 \mathrm{mg} \mathrm{NaCl}, 20 \mathrm{mg} \mathrm{KCl}, 290 \mathrm{mg} \mathrm{Na}{ }_{2} \mathrm{HPO}_{4} .12 \mathrm{H}_{2} \mathrm{O}, 20 \mathrm{mg} \mathrm{KH} \mathrm{PO}_{4}\right.$, $\left.10 \mathrm{mg} \mathrm{MgCl}{ }_{2} \cdot 6 \mathrm{H}_{2} \mathrm{O}, 100 \mathrm{ml} \mathrm{H}{ }_{2} \mathrm{O}\right)$.

\section{RESULTS}

Removal of cumulus oophorus

The experimental results presented in Table 1 show that the time needed for granulosa cell dispersal was shortest in the C.57 strain. In $0.010 \%$ hyaluronidase, the differences between C57 and the other strains were highly significant. In $0.025 \%$ hyaluronidase, only the differences between KP and C.57, and between CBA and C57, reached levels of significance. The eggs of the CBA strain appeared to be the most resistant to hyaluronidase. Even in the $0.025 \%$ solution, a high proportion could not be denuded completely in the course of $2 \mathrm{hr}$ treatment. The differences between the other strains were less evident.

TABLE 1

RAPIDITY OF GRANULOSA CELL DISPERSAL IN DIFFERENT STRAINS OF MICE

\begin{tabular}{|c|c|c|c|c|c|c|}
\hline \multirow{2}{*}{$\begin{array}{c}\text { Hyaluronidase } \\
\text { solution }\end{array}$} & \multirow{2}{*}{$\begin{array}{l}\text { Strain } \\
\text { of } \\
\text { mice }\end{array}$} & \multirow{2}{*}{$\begin{array}{c}\text { No. of } \\
\text { females }\end{array}$} & \multirow{2}{*}{$\begin{array}{c}\text { No. of } \\
\text { ova }\end{array}$} & \multirow{2}{*}{$\begin{array}{c}\text { Time of cumulus dispersal } \\
\text { (min) } \\
\text { Mean } \pm S . D .\end{array}$} & \multicolumn{2}{|c|}{$\begin{array}{l}\text { Ova not denuded } \\
\text { in } 2 \mathrm{hr}\end{array}$} \\
\hline & & & & & No. & $\%$ \\
\hline $0.025 \%$ & $\begin{array}{l}\text { C57 } \\
\text { Outbred } \\
\text { KE } \\
\text { KP } \\
\text { CBA }\end{array}$ & $\begin{array}{l}8 \\
9 \\
6 \\
5 \\
5 \\
9\end{array}$ & $\begin{array}{l}18 \\
43 \\
14 \\
19 \\
36\end{array}$ & $\begin{array}{l}19 \cdot 44 \pm 7 \cdot 65 \\
21 \cdot 40 \pm 3 \cdot 40 \\
25 \cdot 00 \pm 8 \cdot 55 \\
27 \cdot 37 \pm 8 \cdot 06 \\
28 \cdot 50 \pm 10 \cdot 30\end{array}$ & $\frac{-}{\overline{-}}$ & $\overline{-}$ \\
\hline $0.010 \%$ & $\begin{array}{l}\text { C57 } \\
\text { Outbred } \\
\text { KE } \\
\text { KP } \\
\text { CBA }\end{array}$ & $\begin{array}{l}8 \\
9 \\
6 \\
5 \\
9\end{array}$ & $\begin{array}{l}39 \\
42 \\
39 \\
28 \\
57\end{array}$ & $\begin{array}{l}28 \cdot 21 \pm 7 \cdot 11 \\
41 \cdot 82 \pm 17 \cdot 61 \\
44 \cdot 40 \pm 14 \cdot 18 \\
57 \cdot 50 \pm 21 \cdot 70 \\
38 \cdot 92 \pm 13 \cdot 49\end{array}$ & $\begin{array}{r}-9 \\
14 \\
4 \\
20\end{array}$ & $\begin{array}{l}\ldots 1 \cdot 4 \\
35 \cdot 9 \\
14 \cdot 3 \\
35 \cdot 1\end{array}$ \\
\hline
\end{tabular}

\section{Removal of zona pellucida with pronase}

Three main groups of ova were tested in this experiment: unfertilized ova from spontaneous ovulation, unfertilized ova from hormonally treated females and fertilized ova recovered after mating females with $\mathrm{F}_{1} \mathrm{CBA} \times \mathrm{KE}$ males. All these ova were tested on the day of ovulation at about 14.00 hours. A few experiments were performed on unfertilized ova 1 day after ovulation and also on old fragmented ones, found most frequently after induced ovulation.

Significant differences between the experimental groups were found in rapidity of zona removal (Table 2, Text-figs 1 and 2). The time needed to produce lysis of the zona in fresh unfertilized ova was least in the CBA strain and greatest in the KE strain. Ova obtained following hormonally induced ovulation consistently needed a longer period of treatment than ova from spontaneous ovulation, the differences between them reaching significant levels $\mathrm{n}$ the CBA and $\mathrm{C} 57$ strains. 


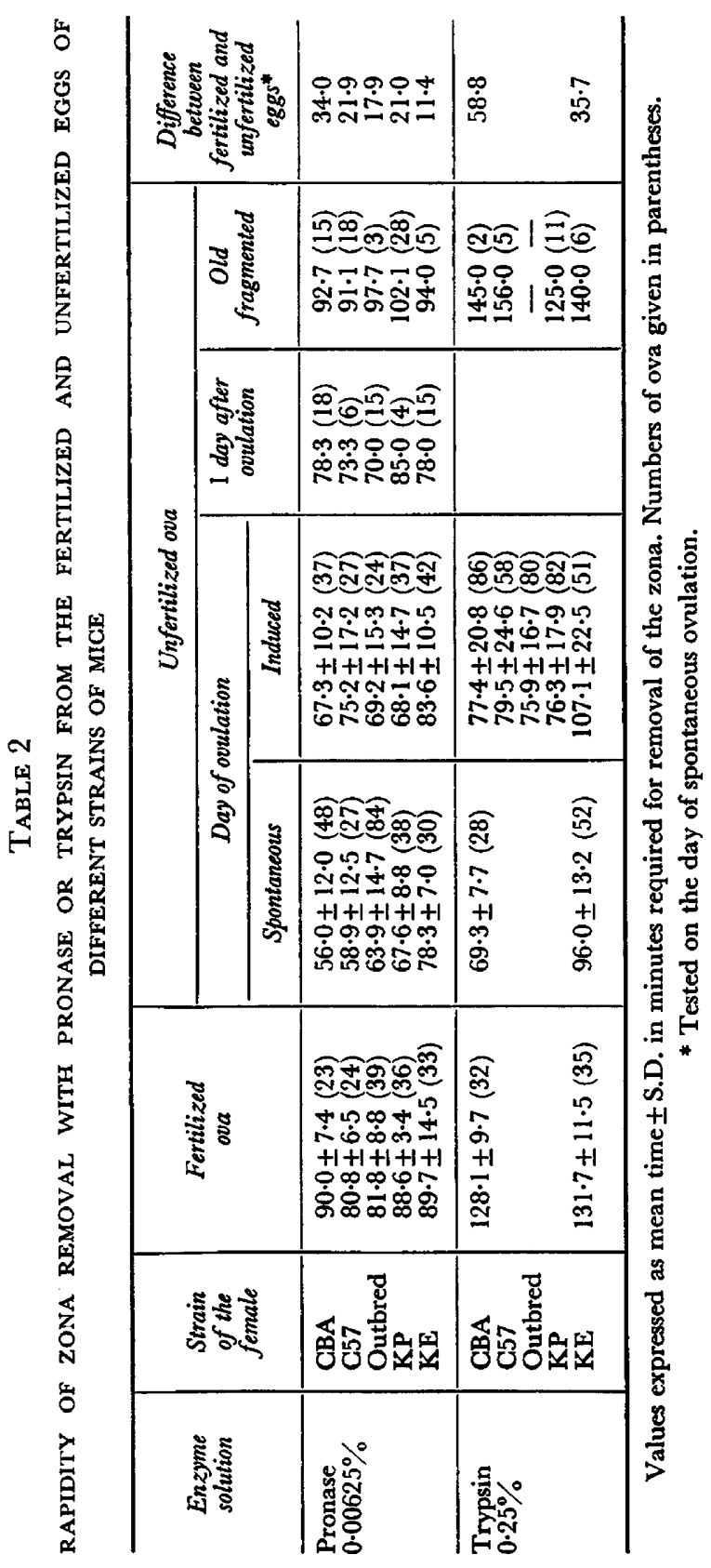




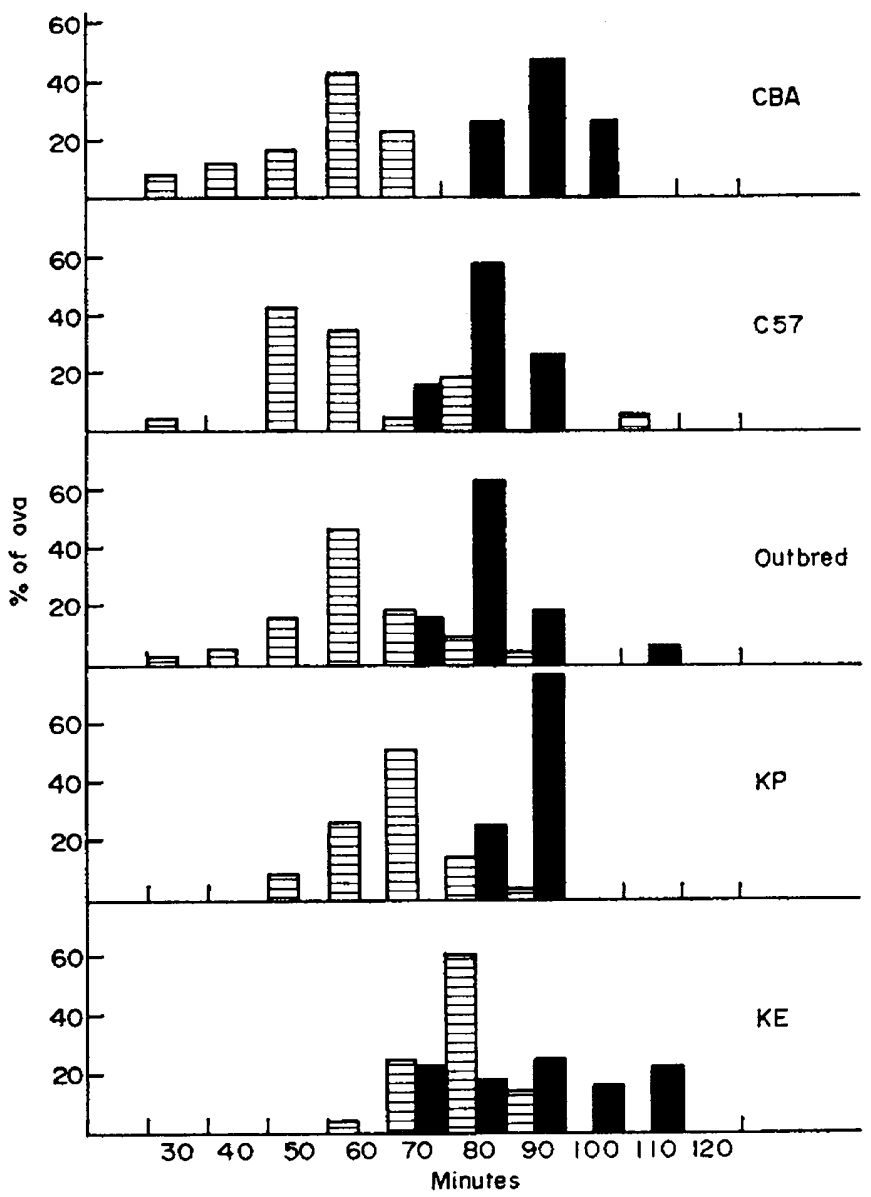

TexT-Fic. 1. Frequency distribution of the time needed for lysis of the zona with pronase. Shaded columns: unfertilized ova from spontaneous ovulation; solid: fertilized ova.

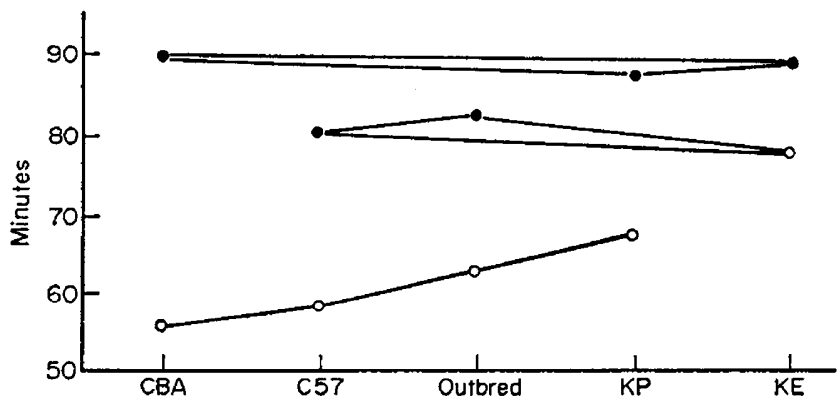

TeXT-FIG. 2. Mean time needed for removal of the zona with pronase. $O$, Unfertilized ova from spontaneous ovulation; $\bullet$, fertilized ova. Lines connecting the points represent nonsignificant differences. 
In all the strains tested, lysis of the zona took significantly more time in fertilized than in unfertilized ova, the difference being most marked in the CBA strain, and least apparent in the KE strain (Table 2). Fertilized ova from the $\mathrm{C} 57$ and outbred strains were significantly less resistant to the action of pronase than fertilized ova from the other strains and did not differ significantly in this respect from unfertilized ova of the KE strain.

The zonae of 1-day-old unfertilized ova tended to be more resistant than the zonae of fresh ova. Those of old fragmented ova were the most resistant in all groups, exceeding even the zonae of fertilized ova. These two groups, however, were not submitted to statistical analysis because of scarcity of material.

\section{Removal of zona pellucida with trypsin}

Fresh, unfertilized ova from hormonally treated females of all the strains tested required about the same duration of treatment with trypsin to accomplish lysis of the zona, except the KE strain ova which were significantly more resistant (Table 2). As with pronase, old fragmented ova were much more resistant than fresh ova.

Only two strains of spontaneously ovulating females were tested: CBA and $\mathrm{KE}$. The females were divided into three groups: unmated, mated with males of the CBA strain and mated with males of the KE strain. Preparations of ova from these females were made at 14.00 hours on the day of ovulation. Unfertilized CBA ova were significantly less resistant to trypsin than KE ones. The time required for lysis of the zona was similar for the fertilized ova of both strains and was significantly longer than that required for unfertilized eggs. The strain of the fertilizing male did not appear to have any observable effect. The difference between the fertilized and unfertilized eggs was much more pronounced in the CBA than in the KE strain.

\section{DISCUSSION}

The present results show that the cell layers surrounding the eggs of mice differ in their resistance to the action of enzymes according to their physiological state. Under the action of pronase and trypsin, lysis of the zona was most rapid in fresh, unfertilized eggs. Ageing rendered the zona more resistant to the action of enzymes, an effect which was most evident in old fragmented ova. The process of fertilization caused a significant rise in the resistance of the zona. This probably reflects the physico-chemical changes referred to as the 'zona reaction' which take place after sperm entry into the vitellus.

A similar difference between the zona pellucida of fertilized and unfertilized eggs in response only to certain enzyme preparations was found by Smithberg (1953) and Gwatkin (1964). The latter expressed the opinion that the changes induced by sperm entry must be rather subtle and require just the right enzyme concentration and timing for their demonstration. These conditions seem to have been fulfilled in the present experiments where enzyme concentrations were much lower than in Gwatkin's experiments.

The most interesting result of the present investigation was the finding that both the granulosa cell layer and the zona pellucida of inbred strains differed 
in their resistance to the action of enzymes. The zona was found to be most resistant and the effectiveness of the zona reaction (as shown by the difference between fertilized and unfertilized eggs of different strains) less efficient in $\mathrm{KE}$ strain ova.

As the preparations from spontaneously ovulated ova were made at 14.00 hours, i.e. about $12 \mathrm{hr}$ after ovulation, the differences in the zona resistance of the unfertilized eggs might be associated with varying rates of ageing of the eggs. The same resistance was obtained, however, with hormonally treated KE strain females which were tested $6 \mathrm{hr}$ after ovulation, i.e. at the time considered to be optimal for performing artificial insemination (Dziuk \& Runner, 1960). It seems, therefore, that the differences obtained reflect the conditions existing at the time of fertilization and may be used to explain the differences in sperm penetration occurring between strains. Fertilized eggs of the KE and C57 strains were characterized by the high incidence of supplementary spermatozoa found in the perivitelline space. The fertilization rate of the $\mathrm{KE}$ eggs was low, $24 \%$ of the eggs remaining unfertilized and about half of them containing spermatozoa in the perivitelline space. By contrast, all the available CBA ova were fertilized and the incidence of supplementary spermatozoa was very low (Krzanowska, 1970).

Entry of supplementary spermatozoa into CBA strain ova may be prevented by the very tight layer of granulosa cells surrounding eggs of this strain which is more resistant to the action of hyaluronidase than in the other strains. Moreover, the zona reaction after fertilization seems to be very effective as judged by the difference between the fertilized and unfertilized eggs in their resistance to the action of proteolytic enzymes.

In C57 strain ova, the granulosa cells were very easily dispersed under the action of hyaluronidase and the zona reaction seemed to be less effective than in the CBA strain.

The most extreme situation was found in the KE strain. Here, the zona pellucida of the unfertilized eggs was so resistant to the action of proteolytic enzymes that it did not differ from that in fertilized eggs of the C57 strain. If the process of sperm entry through the zona is rather slow in this strain, this would favour the simultaneous penetration of more than one spermatozoon, since, in addition, the effectiveness of the zona reaction is extremely low. As the block in the zona only develops after attachment of the spermatozoon to the vitellus, it is likely that this latter process may be impaired in KE strain eggs, which would also explain the lower fertilization rate.

\section{ACKNOWLEDGMENT}

This work was supported by The Polish Academy of Sciences within the project 09.3.1.

\section{REFERENCES}

Bowman, P. \& Mclaren, A. (1970) The reaction of the mouse blastocyst and its zona pellucida to enzymes in vitro. F. Embryol. exp. Morph. 24, 331.

BRADEN, A. W. H. (1958) Variation between strains of mice in phenomena associated with sperm penetration and fertilization. 7. Genet. 56, 37. 
Dziuk, P. J. \& Runner, M. N. (1960) Recovery of blastocysts and induction of implantation following artificial insemination. 7. Reprod. Fert. 1, 321.

Gwatkin, R. B. L. (1964) Effect of enzymes and acidity on the zona pellucida of the mouse egg before and after fertilization. F. Reprod. Fert. 7, 99.

KrZanowsKa, H. (1965) New inbred strains of mice. Mouse News Lett. 32, 54.

KRZANOWSKA, H. (1970) Relation between fertilization rate and penetration of eggs by supplementary spermatozoa in different mouse strains and crosses. $\mathcal{F}$. Reprod. Fert. 22, 199.

Smithberg, M. (1953) The effect of different proteolytic enzymes on the zona pellucida of mouse ova. Anat. Rec. 117, 554. 